\title{
William O. Douglas and The Assault on OBJECTIVITY
}

\author{
Thomas Halper*
}

\begin{abstract}
William O. Douglas, venerated by some and reviled by others, was very much his own man, disdaining his colleagues on the bench and the work they produced. For him, the point of judging was simply to do justice. However, justice is not always self evident, and legal norms and values, like objectivity and stare decisis, are ignored at a high cost. Nor, as it turns out, was his carefully carved authentic persona more than a mask of lies.
\end{abstract}

\author{
KEYWORDS \\ Douglas, Supreme Court, Rule of Law, Legal Realism \\ CONTENTS
}

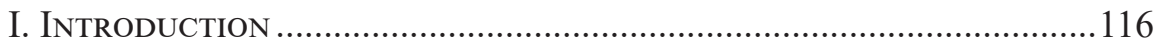

II. The Early Period: Skinner v. OKlahoma ex Rel. Williamson......117

III. The Middle Period: Zorach v. Clausen ....................................... 120

IV. The Later Period: Griswold v. Connecticut ............................... 124

V. The Final Period: Sierra Club v. Morton ....................................128

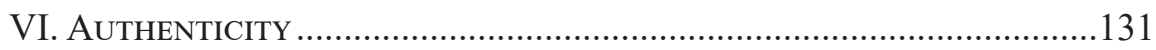

VII. REALISM AND JUSTICE.......................................................... 134

Professor, Political Science, Baruch College \& CUNY Graduate Center.

Thomas.Halper@baruch.cuny.edu 


\section{INTRODUCTION}

Once upon a time, conventional wisdom dictated that the job of the judge was to apply the law objectively, impartially, untainted by politics, and, as the saying went, without fear or favor. To this day, countless court houses are guarded by statues of blindfolded Lady Justice, unsmiling and holding scales, and judicial nominees are queried as to their views on Chief Justice Roberts' trope that the judge's task is simply to "call balls and strikes." Determining constitutionality, as an earlier Justice Roberts announced, is said to be essentially like comparing paint chips at Home Depot: "lay the article of the Constitution which is invoked beside the statute which is challenged and . . decide whether the latter squares with the former." Judges "are human computers."3

Meanwhile, however, legal realists reminded us that laws are often vague or ambiguous, that multiple doctrines might be applied to a single set of facts, that judges are human and will be influenced by their policy, partisan, or ideological preferences, ${ }^{4}$ that judging is "an emotive experience in which principles and logic play a secondary part,"5 and that if they "are a little clever" they will be able to manipulate the results. As there is often more than one legally defensible solution to each case, we must look outside the law, they counsel, if we are to understand why judges decide as they do-and "too often the doctrine that courts invoke is not really the normative standard upon which they really rely." court judge put it, "I pay very little attention to legal rules, statutes, constitutional provisions. A case is just a dispute. The first thing you do is ask yourself-forget about the law - what is a sensible resolution of this dispute?"8

1 Confirmation Hearing on the Nomination of John G. Roberts, Jr. to Be Chief Justice of the United States, Hearing before the S. Comm. on the Judiciary, 109th Cong. 56 (2005). 2 United States v. Butler, 297 U.S. 1, 62 (1936).

3 Lee Epstein et al., The Behavior of Federal Judges: A Theoretical and Empirical Study of Rational Choice 50 (2013). The authors are highly critical of this model.

4 Charles G. Haines, General Observations on the Effects of Personal, Political, and Economic Influences in the Decisions of Judges, 17 ILL. L. Rev. 96, 116 (1922). More recently, an examination of parole decisions of Israeli judges found that food breaks appeared to have major effects on their rulings. Shai Danziger, Jonathan Levav, \& Liora Avnaim-Pesso, Extraneous Factors in Judicial Decisions, 108 Proc. NAT'L. ACAD. SCI. 6889 (Apr. 26, 2011).

5 Hessel Ytema, The Hornbook Method and the Conflict of Laws, 37 YaLE L. J. 468, 480 (1928).

6 Max Radin, The Theory of Judicial Decision: Or How Judges Think, 11 A.B.A. J. 357, 361 (1925).

7 Brian Leiter, Legal Realism and Legal Doctrine, 163 U. PA. L. Rev. 1975 (2015). A popular theme among political scientists is the "attitudinal model," according to which justices "may freely implement their personal policy preferences." JefFrey A. SEGAL \& Harold J. Spaeth, The Supreme Court and the Attitudinal Model Revisited 111 (2002). That judges "legislate from the bench" has become a cliché among pundits. Eric Segall, Supreme Court Justices Are Not Really Justices, Slate (Nov. 14, 2014); Rachel DiCarlo Currie, The Supreme Court Shouldn't Be So Important, InDeP. Women's Forum (Sept. 27, 2016).

8 Richard A. Posner, quoted in Adam Liptak, An Exit Interview with Richard Posner, Judicial Provocateur, N.Y. Times, Sept. 11, 2017 (emphasis added). 
It is the burden of this essay that Justice William O. Douglas learned the realists' lesson well, perhaps too well. Their point, easily vulgarized - that judicial reasoning is mere rationalizing, a sophisticated effort at covering up inexorable subjectivity - entails a very practical conclusion - why waste time and energy on judicial opinions? Why, especially if one has a dozen other urgent calls on his time? Hiking, writing memoirs and travel books, dreaming of becoming president. Why, in any case, pursue elegantia juris, when the point of judging is justice. Everything else, Douglas seems to have believed, when it is not beside the point, is simply a means to this end.

How much of his opinions represent Douglas' own words? In the current era when most justices routinely farm out first drafts to law clerks - and some justices play even a lesser role - Douglas for many years bucked the trend, even insisting on fewer clerks than his colleagues. Still, by 1965, his clerks produced first drafts of his per curiam, concurring, and dissenting opinions, by the early 1970 s occasional majority opinions, as well, and after his serious stroke on the last day of 1974 their role increased substantially. ${ }^{10}$ Taking this into account, consider his opinions in high profile cases drawn from each decade of his tenure, all cases he plainly considered of high importance.

\section{The Early Period: Skinner v. OKLahoma eX Rel. WILLIAMSON}

A century ago, eugenics was a reform idea that captivated enlightened opinion in America and Europe. ${ }^{11}$ Theodore Roosevelt, Woodrow Wilson, Margaret Sanger, George Bernard Shaw, Harry Emerson Fosdick, A. Lawrence Lowell, Alexander Graham Bell, Helen Keller, John Maynard Keynes, H.G. Wells-many of the most prominent intellectuals of the age advocated improving the human race by selective breeding, legitimating racism with a faux scientific respectability. ${ }^{12}$ In this scenario, coercion was often required, and in 1927, the Supreme Court approved a compulsory sterilization law in the notorious Buck v. Bell. ${ }^{13}$ The Nazis pricked eugenics' bubble of respectability by implementing it through mass murder, ${ }^{14}$ but

9 According to one biographer, Blackmun "delegated virtually all opinion drafts to his clerks [and] spent hundreds of hours each term cloistered in the justices' library, painstakingly checking his clerks' citations and closely monitoring their drafts, ever alert to their grammatical and spelling errors - while they largely sculpted the substantive elements of his jurisprudence.” Tinsley E. Yarbrough, Harry A. Blackmun: The Outsider Justice 346 (2008).

10 Marshall L. Small, William O. Douglas Remembered: A Collective Memory by WOD's Law Clerks, 32 SuP. Cт. His. 297, 304 (2007).

11 Thomas C. Leonard, Illiberal Reformers: Race, Eugenics and American Economics in the Progressive Era ch. 7 (2016).

12 On the history of eugenics, see Daniel Kevles, In the Name of Eugenics: Genetics aNd the Uses of Human Heredity (1985).

13 Buck v. Bell, 274 U.S. 200 (1927).

14 The influence of American eugenics advocates on Nazis is detailed in Barry A. Mehler, A History of the American Eugenics Society, 1921-1940, ch. 6 (1988) (unpublished Ph.D. dissertation, University of Illinois) (on file with the University of Illinois at UrbanaChampaign); Stefan Kuhl, The Nazi Connection: Eugenics, American Racism, and 
sterilizations continued to be practiced in a number of states even after World War II, though the new laws "at least in appearance, . . . respect[ed] some form of reproductive choice." ${ }^{\prime 15}$ In the end, over sixty thousand Americans were sterilized. ${ }^{16}$

Consider, in this light, Skinner v. Oklahoma, ${ }^{17}$ one of the first important opinions Douglas produced. The case concerned Oklahoma's Habitual Criminal Sterilization Act that required the sterilization of persons convicted two or more times of "felonies involving moral turpitude," provided that the person "may be rendered sexually sterile without detriment to his or her general health." ${ }^{18}$ Certain offenses, including "violations of the prohibitory laws, revenue acts, embezzlement, or political offenses" were expressly excluded. Jack T. Skinner, convicted twice of armed robbery and once of stealing six chickens, was ordered sterilized. ${ }^{19} \mathrm{He}$ had offered data countering the eugenic premise of the statute, indicating that Oklahoma prisoners were unlikely to come from families of convicted criminals, but the court had refused to permit him to present the evidence. He appealed to the Oklahoma Supreme Court, which, deferring to the legislature, upheld his conviction, ${ }^{20}$ and then to the United States Supreme Court.

Douglas, writing for the majority, struck down the law as violative of the Fourteenth Amendment's equal protection clause. An embezzler may steal far more money than a robber, and a chicken thief may steal far less than "a Bailee of the property [who] fraudulently appropriates it," ${ }^{21}$ yet both the embezzler and the Bailee escape sterilization; this, Douglas wrote, constitutes "a clear, pointed, unmistakable discrimination." 22

But it is not only the law's inconsistent coverage that Douglas objects to. His very first sentence refers to "a sensitive and important area of human rights," which he then defines as "the right to have offspring," and later he speaks of "the basic civil rights of man," ${ }^{23}$ marriage and procreation. ${ }^{24}$ Because these basic rights are implicated, Douglas announces that the statute will be subjected to strict scrutiny. ${ }^{25}$

German National Socialism ch. 8 (1994); Edwin Black, War Against the Weak: Eugenics and America's Campaign to Create a Master Race (2d ed. 2012).

15 Mary Ziegler, Reinventing Eugenics: Reproductive Choice and Law Reform after World War II, 14 CARDOZo J. L. \& Gender 319, 323 (2008).

16 The recent development of gene editing has generated fears of a new, high technology kind of eugenics. Robert Pollack, Lurking in the Shadow of CRISPR, 348 SCI. 871 (2015); Carolyn Brokowski et al., Cutting Eugenics out of CRISPR-Cas 9, 6 Eтнics Biology, EngineERING \& Med.: INT'L J. 263 (2015).

17 Skinner v. Oklahoma, ex rel. Williamson, 316 U.S. 535 (1942).

18 OKLa. Stat. AnN. tit. 57, §§ 171-195 (West). The original law, passed in 1931, provided for the sterilization of the insane; as amended, after lobbying by eugenics advocates, it applied also to habitual criminals.

19 On his trial, see Victoria F. Nourse, In Reckless Hands: Skinner v. OkLahoma and the Near-Triumph of American Eugenics ch. 7 (2008).

20 Skinner v. State, ex rel. Williamson, 189 Okla. 235, 115 P.2d 123 (Okla. 1941).

$21 \quad$ Skinner, supra note 17 at 539.

22 Id. at 541. In this, Douglas echoed an argument of Guy Andrews, one of Skinner's lawyers. See Nourse, supra note 19, at 138. Frankfurter successfully pressed the argument on Douglas. Id. at 142-43. The two had not yet become enemies.

23 Skinner, supra note 17, at 536.

$24 \quad I d$. at 541.

25 Id. Skinner's lawyers argued that sterilization, by eliminating the risk of pregnancy, increased the likelihood of promiscuity. Dubler maintains that this is a useful way of 
Today, a long list of cases ${ }^{26}$ has established that the term requires a compelling governmental interest and narrowly tailored means, the compelling interest justifying the abridgement of rights and the narrow tailoring ensuring that the abridgement be as little as possible. Perhaps because strict scrutiny was new to the Court, it was so undeveloped that Douglas seems to have taken it simply as a turn of phrase meaning that the Court would greet the law with considerable skepticism. ${ }^{27}$

The equal protection claim raises the question: suppose Oklahoma had not offered exceptions to the moral turpitude coverage, leaving embezzlers and chicken thieves treated alike? This is not a hypothetical, as the law had a severability clause, which presumably would raise the issue. Douglas' answer is that the Oklahoma Supreme Court upheld the law "without reference to the severability clause," ${ }^{28}$ and so he would leave the question "for adjudication by the Oklahoma court." 29 Yet as the Oklahoma court upheld the entire law, it would have no reason to address severability; in any event, whether the Oklahoma court addressed severability would not foreclose Douglas from addressing it. Douglas ends the discussion by writing that "it is by no means clear" ${ }^{30}$ whether severability would save the law, undermining his refusal to consider the issue. The constitutionality of compulsory sterilization, as a result, is left standing, if wobbly. Had he dismissed eugenics as junk science, he might have eliminated the rationale for the law, but though he averred that "We have not the slightest basis for inferring that [thieving] has any significance in eugenics," ${ }^{11}$ he declined to pass on "the state of scientific authorities respecting inheritability of criminal traits." ${ }^{232}$ Buck v. Bell was not reversed.

As to the newly found rights to marry and to procreate, what kinds of rights are they? If I experience difficulty in procreating, is the state obliged to help me, for example, by paying for appropriate medical procedures? If I have a right to marry, may the state charge me for exercising that right by forcing me to buy a license? Or force me to take a blood test? Or ban me from marrying members of my family? Is it obliged to subsidize my membership in Match.com, if I am unable to find a spouse on my own? If these are, indeed, legal rights, what is their constitutional or statutory basis? $?^{33}$ Why raise the subject of marriage, inasmuch as Oklahoma is not preventing Skinner from getting married? Nor is marriage, a legal construct that

understanding the case, but inasmuch as she concedes that the Court "did not explicitly address" this contention, her argument is hard to sustain. Ariela R. Dubler, Sexing Skinner: History and the Politics of the Right to Marry, 110 Colum. L. Rev. 1348, 1348, 1362 (2010).

26 E.g., Palmore v. Sidoti, 466 U.S. 429, 432 (1984); Wygant v. Jackson Bd. of Educ., 476 U.S. 267, 274 (1986); United States v. Paradise, 480 U.S. 149, 154-55 (1987); Adarand Constructors v. Pena, 515 U.S. 200, 237 (1995).

27 Stone, who originated the concept in his famous footnote four in United States $v$. Carolene Products, 304 U.S. 144, 152 (1938), made no mention of strict scrutiny in his concurrence.

28 Skinner, supra note 17 at 542.

$29 \quad I d$. at 543.

$30 \quad I d$.

$31 \quad I d$. at 542.

$32 \quad I d$. at 538.

33 A dissenter on the Oklahoma Supreme Court, Judge Osborn, asserted that "the right to beget children is one of the highest natural and inherent rights," citing the state and national constitutions, but Douglas offered no citation to the Constitution. 
confers formal benefits and responsibilities, comparable to procreation, which, as he says, "is basic to the perpetuation of the race." ${ }^{34}$ If a woman were sentenced to a term in prison that extended through her menopause, could she claim that her right to procreate was abridged? What of a man sentenced to life in prison $?^{35}$ May a judge offer a convicted defendant probation, conditioned on his not procreating? ${ }^{36}$ Does the right to procreate imply a right not to procreate, that is, a right to contraception or an abortion? Interestingly, though the law seems to target the lower classes, who are more likely to be chicken thieves and less likely to be embezzlers, Douglas sidestepped its class basis, for his solution was not at all class based, but instead a declaration of a new right (or rights) to be enjoyed by all.

As to whether the punishment violated the Constitution's ex post facto prohibition, Douglas simply avoided the question. Skinner's convictions occurred in 1926, 1929, and 1934. The Habitual Criminal Sterilization Act was not adopted until 1935. Oklahoma argued that the purpose of the law was eugenic, not punitive, and thus that the prohibition that was confined only to criminal matters would not apply. ${ }^{37}$ However, Skinner certainly understood sterilization as punitive, ${ }^{38}$ and the law expressly tied it to criminal conduct, and so a counter argument could easily have been made. Douglas, seizing the opportunity to declare basic rights, was plainly not interested in basing his decision on such narrow grounds. ${ }^{39}$

Douglas' opinion has an unsettling, unfinished quality. Brash in its proclaiming rights, it does not bother to sketch them or identify how they are tethered to the Constitution nor does it make an effort to elucidate the meaning of the key corollary to these rights, strict scrutiny. Nor does it seize the obvious opportunity to invalidate compulsory sterilization or even to reconsider Buck v. Bell. It is, then, an odd mixture of the bold and the timid.

\section{The Middle Period: Zorach v. Clausen}

The First Amendment provides, inter alia, that "Congress shall make no law respecting an establishment of religion." Beyond barring the creation of an American version of the Church of England, the words simply invite speculation.

Skinner, supra note 17, at 536.

35 In Gerber v. Hickman, 264 F.3d 882 ( $9^{\text {th }}$ Cir. 2001), the court held that the right to procreate applied to a life term prisoner seeking to impregnate his wife via artificial insemination. In Turner v. Safley, 482 U.S. 78 (1987), the Supreme Court held that the right to marry applies to prisoners.

36 A father of nine, found guilty of a felony of intentionally refusing to pay child support, could be offered probation, subject to this condition. Wisconsin v. Oakley, 629 N.W. 2d 200 (Wis. 2001). On the other hand, the Indiana Court of Appeals turned down a similar probation offer presented to a woman found guilty of neglect of a dependent in the death of her infant son. Trammell v. State, 751 N.E.2d 283 (Ind. Ct. App. 2001).

37 The same argument was used to refute at the state level the charge that sterilization constituted "cruel and unusual punishment" under the Eighth Amendment. See Skinner supra note 20, at 126.

38 Skinner, married thirty-seven years, died childless. See NourSE, supra note 19, at 157.

39 Skinner, supra note 17, at 538. Nor did ex post facto interest Stone and Jackson in their concurrences, though both seemed uneasy with Douglas' bold reach. 
Do they imply, in Jefferson's famous terms, "a wall of separation"? 40 Or do they permit state and church to reach some kind of accommodation? The Supreme Court, it must be confessed, has not always addressed the issue with consistency or analytical rigor. ${ }^{41}$ In a key case, in which it declared that "the wall between church and state ... must be kept high and impregnable [without] the slightest breach," for example, the Court upheld a state program reimbursing parents for the cost of bussing their children to parochial schools. ${ }^{42}$

Decided a decade after Skinner, Zorach v. Clausen $^{43}$ concerned a New York City released time program that permitted students, on request of their parents, to leave public school during classes to receive religious instruction at houses of worship, which in turn made weekly attendance reports to the schools. ${ }^{44}$ Other students remained in school. Tessim Zorach, a taxpayer and resident of the city, asked that the program be declared unconstitutional as contravening the First Amendment's establishment clause. As Douglas summarized Zorach's arguments, "the weight and influence of the school is put behind the program for religious instruction; public school teachers police it, keeping tabs on students who are released; the classroom activities come to a halt while the students who are released for religious instruction are on leave; the school is a crutch on which the churches are leaning for support in their religious training; without the cooperation of the schools this 'released time' program . . . would be futile and ineffective." ${ }^{\prime 5}$

Douglas agrees with Zorach that the real issue is whether New York abridged the establishment clause, ${ }^{46}$ clearing the way for a discussion of an obvious recent establishment case, McCollum v. Board of Education, ${ }^{47}$ which struck down a religious instruction program in Illinois. McCollum is an inapposite precedent, he explains, because here "classrooms were used for religious instruction and the force of the public school was used to promote that instruction," whereas in Zorach "the public schools do no more than accommodate their schedules to a program of outside religious instruction." ${ }^{48}$ A central consideration, he observes, is coercion. If

40 Letter from Thomas Jefferson to the Danbury Baptist Association (Jan. 1, 1802), reprinted in The Works of ThOMAS JeFFerson 346 (Paul L. Ford ed., 1905).

41 Stanley Fish, Think Again: Contrarian Reflections on Life, Culture, Politics, Religion, LaW and EduCATION 290 (2015).

42 Everson v. Bd. of Educ., 330 U.S. 1, 18 (1947). The rationale, that the aid was intended to help the parents and children and not the school, ignored the obvious fungibility of money, for the support plainly had the effect of helping the church by permitting it to use the money for other purposes. Madison famously opposed spending even a threepence of public funds to support teachers of the Christian religion: James Madison, Memorial and Remonstrance against Religious Assessments, in Selected Writings of James MADISON 23 (Ralph Ketchum ed., 2006).

43 Zorach v. Clauson, 343 U.S. 306 (1952).

44 N.Y. Education Law sec. 3210-1 authorized "Absence for religious observance and education ... under rules that the commissioner [of education] shall establish."

45 Zorach, supra note 43, at 309.

$46 I d$. at 310 . The free exercise clause is irrelevant, he states, because " $[\mathrm{n}] \mathrm{o}$ one is forced to go to the religious classroom and no religious exercise of instruction is brought to the classrooms of the public schools." Id. at 311.

47 Illinois ex rel. McCollum v. Bd. of Educ. of Sch. Dist. No. 71, Champaign Cty., Ill., 333 U.S. 203 (1948).

48 Zorach, supra note 43, at 315. 
schools coerced students to attend, "a wholly different case would be presented."49 But there is "no evidence in the record" 50 of such coercion.

The constitutionally mandated church-state separation, he says, is "complete and unequivocal and absolute," but this implies a "common sense" approach, not one that is "hostile, suspicious, and even unfriendly." ${ }^{51}$ Invalidating the New York law "would have wide and profound effects," 52 for it would rule out such commonplace acts of cooperation as acceding to a request from a Jewish student to be excused for Yom Kippur or from a Protestant student wishing to attend a family baptism. "We are a religious people," he declares, "whose institutions presuppose a Supreme Being." ${ }^{\circ 3}$ Of ten opinions Douglas wrote on the establishment clause, this was the only one to speak for a majority and, perhaps not coincidentally, the only one to turn down an establishment claim.

An odd part of the opinion is that the issue it identifies as central is given only cursory treatment, for the question of coercion is allotted only a single seven line paragraph. How to determine if a given practice is coercive? The most obvious answer is: examine how it operates. Though each side presented information on this point, Douglas rejects considerations of "practical experience" because he believes they involve extraconstitutional considerations, like the wisdom or educational efficiency of the system. ${ }^{54}$ Yet considerations of practical experience need not be extraconstitutional. Indeed, such considerations are often a staple in constitutional inquiries. Yick Woo v. Hopkins, ${ }^{55}$ for example, struck down a San Francisco ordinance based not on its wording but on its operation; Brown v. Board of Education ${ }^{56}$ famously referred to the practical effects of racial segregation on black children; Gideon v. Wainwright ${ }^{57}$ was based on the real life consequences of the absence of legal representation in criminal cases. The list could be extended on and on. Dismissing the constitutional relevance of "practical experience," in short, is bizarre and would be inexplicable, had Douglas not failed to follow his own advice, for he announces that there is "no evidence in the record" of coercion. ${ }^{58}$

Only two pages later, in a footnote, does he disclose why there is no evidence of coercion: "The New York State Court of Appeals declined to grant a trial on this issue, noting . . . that appellants had not properly raised their claim." 59 Or as Frankfurter acidly put it in his dissent, "there could be no proof of coercion, for the appellants were not allowed to make proof of it." He added, "When constitutional issues turn on facts, it is a strange procedure indeed not to permit the facts to be established." ${ }^{60}$ Why, one asks, hold religious instruction during school hours? The answer, according to research conducted around the time of Zorach, is that "where released time systems have been abandoned, attendance at religious classes

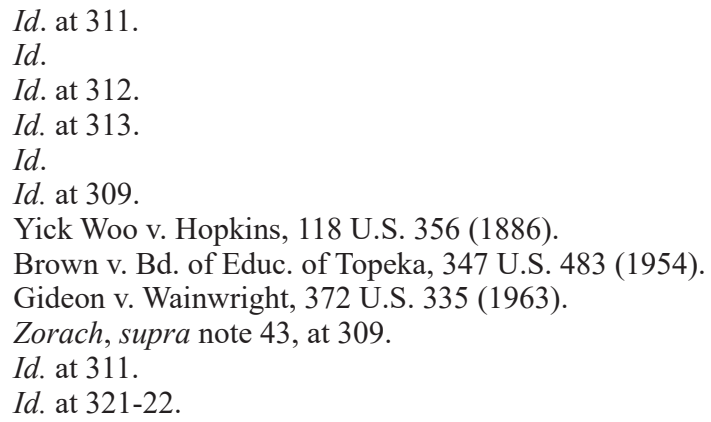


has declined." ${ }^{61}$ For Black the element of coercion in mandatory education taints released time. ${ }^{62}$ For Douglas, the absence of evidence is evidence of absence.

A larger, more abstract issue is whether the establishment clause requires official neutrality among religions or as to religion itself. Douglas clearly favors the first option. "We sponsor an attitude on the part of government that shows no partiality to any one group. . The government must be neutral when it comes to competition between sects [and is not required to] show a callous indifference to religious groups." ${ }^{\prime 3}$ In an earlier draft, he wrote, "we are a God-fearing people whose every institutions [sic] presuppose not atheism or agnosticism, but a faith in God." ${ }^{\prime 4}$ From this premise, he infers a legitimate role for government in protecting religion and a First Amendment aimed only at barring the preference of one religion over another ${ }^{65}$ In any event, he concludes, the state did "no more than accommodate [the students'] schedules to a program of outside religious instruction." opinion that begins with a declaration of separation concludes with a paean to accommodation, though the problem with applying the accommodationist rationale is that it is intended to relieve religions of burdens, not to confer benefits.

Douglas' opinion leaves the impression that he was favorably disposed toward religion and because the accommodationist stance was most connected with Catholics, with the Church, as well. But though the son of a Presbyterian minister, by the time of Zorach he had long since become hostile to religion and made no attempt to hide it, confessing to "a residue of resentment of which I have never quite got rid-resentment against hypocrites in church clothes. ${ }^{967}$ Religion, he believed, was a powerful means of social control, with clergy "defenders of the status quo and against the rabble." ${ }^{68}$ As to the Catholic Church, he seems to have shared a prejudice then common among liberal intellectuals: ${ }^{69}$ Wiecek wrote of Douglas'

61 Russell N. Sullivan, Religious Education in the Schools, 14 LAW \& ConTEMP. Probs. 92, 111 (1949).

62 A prominent Catholic authority on church-state relations retorted that nearly all children attend school not because the law requires it, but rather because their parents recognize that it is their "natural duty to educate their children"; the compulsory rule, then, applies only to the small number whose parents ignore this duty. George E. Reed, Church-State and the Zorach Case, 27 Notre DAme L. Rev. 529, 548 (1952).

63 Zorach, supra note 43, at 314.

64 James E. Zucker, Better a Catholic than a Communist: Reexamining McCollum v. Illinois and Zorach v. Clausen, 93. VA. L. REv. 2069, 2116 (2007).

65 Black, dissenting, countered that a state preferring believers over nonbelievers "is just what . . . the First Amendment forbids. It is because the Framers understood that Americans are a religious people that they intended "to insure that no one powerful sect or combination of sects could use political or governmental power to punish dissenters [and preserve] the freedom of each and every denomination and of all nonbelievers [to] be maintained." Zorach, supra note 43, at 318-19. Similarly, Jackson in his dissent, declared, "The day the country ceases to be free from irreligion it will cease to be free for religion-except for the sect that can win political power." Id., at 325.

$66 \quad$ Id. at 315.

67 William O. Douglas, Go East, Young Man: The Early Years 62 (1974); James F. Simon, InDEPENDENT Journey 1-2 (1973).

68 See Douglas, supra note 67, at 14.

69 John T. McGreevy, Thinking on One's Own: Catholicism in the American Intellectual Imagination, 1928-60, 84 J. Am. Hist. 97 (1997); Mark S. Massa, The New and Old AntiCatholicism and the Analogical Imagination, 62 Theological STUd. 549, 553-61 (2001). 
"scarcely concealed anti-Catholicism," "70 and Powe of his "thorough-going, longstanding anti-Catholicism." should have made acting on this hostility easier. Moreover, Zorach concerned children and education, and much of the opposition to the Church focused on its efforts to socialize the young. All this might lead to a confident prediction that Douglas would oppose the released time practice.

Yet in Zorach, Douglas sounds like a believer sympathetic to the Church's needs. How is this to be explained? Two authorities, aware of Douglas' powerful desire to become president, attribute his opinion to "the bonds of political ambition," "72 apparently referring to a need to attract Catholic voters to aid his bid for the Democratic presidential nomination that summer. This, however, is not entirely persuasive; Douglas had ruled out seeking the presidency three months before Zorach, and in his opinions in contemporaneous national security cases $^{73}$ and in calling for United States recognition of Communist China, ${ }^{74}$ he was alienating precisely this segment of the electorate. A decade later, Douglas came around to the separatist position in a series of Sunday blue laws cases, ${ }^{75}$ leaving Zorach an isolated exception to the rule. His stance here is difficult to understand.

\section{The Later Period: Griswold v. Connecticut}

Perhaps no right today is the subject of as much discussion as privacy. Noting fears and annoyances, Americans feel that their privacy is more threatened than ever before, usually as a consequence of modern technology. ${ }^{76}$ Yet though it has become a cliché that modern life imperils privacy, arguably privacy itself is an artifact of

70 William M. WieceK, LiberTy under LaW: The Supreme Court in AMERICAN Life 173 (1988).

71 Lucas A. Powe, Jr., The Warren Court and American Politics 368 (2000).

72 Bruce Allen Murphy, Wild Bill: The Legend and Life of William O. Douglas 357 (2003); David Louisell, The Man and the Mountain: Douglas on Religious Freedom, 73 YAle L. J. 975, 995 (1964).

73 Dennis v. United States, 341 U.S. 494 (1951); Adler v. Bd. of Educ., 485 U.S. 380 (1952).

74 Justice Douglas Urges China Recognition, Wash. Post, Sept. 1, 1951.

75 McGowan v. Maryland, 366 U.S. 420 (1961); Gallagher v. Crown Kosher Meat Market, 366 U.S. 617 (1961); Two Guys v. McGinley, 366 U.S. 582 (1961); Braunfeld v. Brown 366 U.S. 599 (1961). In fact, one study concluded, "In its fully developed form, Douglas' literal reading of the establishment clause as proscribing all laws regarding an establishment of religion led him to find the clause violated by any government assistance to religion, no matter how minuscule, how indirect, or how long-standing and widely accepted." Nadine Strossen, The Religion Clause Writings of Justice William O. Douglas, in He Shall Not Pass This Way Again 91, 96 (Stephen L. Wasby ed., 1990). In his subsequent opinions, Douglas never acknowledged that he changed his mind, even citing the "We are a religious people" statement in Zorach in a school prayer case striking down the practice. Engel v. Vitale, 370 U.S. 421, 437, 442 (1962).

76 E.g., Urs Gasser, Recoding Privacy Law: Reflections on the Future Relationship among Law, Technology, and Privacy, 130 Harv. L. Rev. 61 (2016); Wolter Pieters, Explanation and Trust: What to Tell the User in Security and AI?, 13 Eтнics \& INFo. Teсn. 53 (2013); Morgan Hochheiser, The Truth Behind Data Collection and Analysis, 32 J. Marshall J. Info Tech \& Privacy L. 33 (2015). 
modern life, which offers unprecedented opportunities to be by ourselves at home, at work, and in transit, plus as ciphers in large impersonal organizations. Given this history, it is not surprising that the Constitution is silent as to privacy nor that this silence came to be seen as an anachronistic defect requiring correction.

Which brings us to Griswold v. Connecticut. ${ }^{77} \mathrm{Of}$ all the hundreds of opinions Douglas produced, Griswold may well be the most significant. Connecticut had made it a crime to use contraceptives or to provide information counseling their use. ${ }^{78}$ Estelle Griswold, the executive director of Planned Parenthood in Connecticut, gave contraceptive information and counseling to married couples, and was convicted and fined $\$ 100$. Her conviction was affirmed at the state level, and she successfully appealed to the Supreme Court.

Douglas begins his consideration of the merits, declaring, "We do not sit as a super-legislature to determine the wisdom, need, and propriety of laws that touch ... social conditions." ${ }^{79} \mathrm{He}$ then establishes that the Constitution embodies certain rights not expressly mentioned, relying on a handful of precedents. These "peripheral rights," ${ }^{80}$ implied by the expressed rights, "suggest that specific guarantees in the Bill of Rights have penumbras, formed by emanations from these guarantees that help give them life and substance." ${ }^{\prime 1} \mathrm{He}$ closes the case by arguing that penumbras from the First (the right to associate), Third (the right to be free from being forced to quarter soldiers in one's home during peace time), Fourth (the right to be secure in one's person and be free from unreasonable searches and seizures), Fifth (the privilege against self incrimination), and Ninth (the Constitution's enumeration of rights is not necessarily exclusive) Amendments, together create a zone of privacy protected by the Constitution. ${ }^{82}$ At this point, Douglas turns to the fact that Griswold was counseling married couples. "Would we allow the police to search the sacred precincts of marital bedrooms for telltale signs of the use of contraceptives?" he asks, following with a paean to marriage as "an association for as noble a purpose as any involved in our prior decisions." $" 83$

Often, apparently revolutionary rulings in hindsight may be seen as merely culminating a lengthy incremental process. The famous Brown desegregation case, ${ }^{84}$ for example, which struck many as a bolt from the blue, actually followed from a

77 Griswold v. Connecticut, 381 U.S. 479 (1965).

78 Gen. Statutes of Conn., §§53-32, 54-196 (1958 rev.). The law had essentially been unenforced, rendering it impervious to judicial review. Poe v. Ullman, 367 U.S. 497 (1961). Griswold was concocted to test the law.

79 Griswold, supra note 77, at 482.

$80 \quad I d$. at 483.

$81 \quad I d$. at 484.

$82 \quad I d$.

83 Id. at 585-86. Feldman suggests that "Douglas, after all, loved the institution [of marriage] so much he entered into it four times." Noah Feldman, Scorpion: The Battles and Triumphs of FDR's Great Supreme Court Justices 427 (2010). Douglas, a notorious and often abusive womanizer, left his twenty-five year old wife a few weeks after his Griswold decision, and the next year married a twenty-three year old cocktail waitress. Though the National Father's Day Committee named him Father of the Year, Douglas had a strained relationship with his children, who regarded him as "scary." MuRPHY, supra note 72 , at $287,198$.

84 Brown, supra note 56. 
series of holdings ${ }^{85}$ and was really the next logical step. Occasionally, however, the revolutionary ruling has no obvious forebears. New York Times v. Sullivan, ${ }^{86}$ which rewrote the law of libel, is one such case. Griswold is another. ${ }^{87}$ Such acts of discontinuity might seem to require more than the usual level of justification. But in Griswold, the constitutional right to privacy rests on a single paragraph on penumbras and emanations.

Thus, Douglas makes no effort to rebut contrary views. For example, he assumes that the various emanations from the five amendments add up to a right to privacy. But if this is so, why have the five amendments and not a single privacy amendment, for a generalized right to privacy might render them superfluous? Or why not conclude that the Framers favored only the privacy related rights expressed in the amendments and nothing more?

To the obvious question, If the Framers wanted a general right to privacy, why did they not include it in the Constitution, Douglas' response seems to be: let us remedy the oversight. An advocate of the living Constitution, he appears to have taken it for granted that it was the Court's responsibility to update the document to take into account evolving beliefs and opinions. Harlan, in his concurrence, criticized the "constitutional outlook . . . to keep the Constitution in supposed "tune with the times," "88 and Black, in his dissent, made the same point even more emphatically, comparing Griswold with the notorious Lochner case. ${ }^{89}$ Douglas disavowed this charge, ${ }^{90}$ but Justice Peckham might have used emanations (from the contract and due process clauses) as a rationale, if only he had been as creative as Douglas. Black believed that a right to privacy should be added to the Constitution through the "old-fashioned" amending process. ${ }^{91}$ If the constitutional right were formally proposed, there would be a text to parse, plus congressional hearings and debates, not to mention analyses by lawyers, pundits, politicians, and ordinary citizens. This elaborate discourse would certainly not avoid all confusion as to the meaning of the text. ${ }^{92}$ But it would clearly be more helpful than examining only the cryptic term, "right to privacy." In ordinary speech, we may think of peeping toms or stolen diaries as privacy infringements. Would we also think of abortions? ${ }^{93}$ Possibly. But

85 Missouri ex rel. Gaines v. Canada, 305 U.S. 337 (1938); Sipuel v. Bd. of Regents, 332 U.S. 631 (1948); McLaurin v. Oklahoma State Regents, 339 U.S. 637 (1950); Sweatt v. Painter, 339 U.S. 629 (1950).

86 New York Times Co. v. Sullivan, 376 U.S. 254 (1964).

87 Privacy had been discussed, at least since Samuel Warren and Louis Brandeis' classic, The Right to Privacy, 4 Harv. L. Rev. 193 (1890), and numerous cases had been decided on the tort of the invasion of privacy. But this is very different from a constitutional right to privacy.

88 Griswold v. Connecticut, 381 U.S. 479, 501 (1965).

89 Lochner v. New York, 198 U.S. 45 (1905).

90 Griswold, supra note 77, at 482.

$91 \quad I d$. at 522.

92 Justice Scalia would have had no patience with the use of legislative history. See Antonin Scalia, A Matter of Interpretation: Federal Courts and the LaW 29-37 (1997). Still, as an originalist, he would have had a formal text to explicate.

93 On how Griswold's marital contraception privacy was transmuted in less than eight years into Roe's abortion privacy, see David J. GaRrow, LiberTy and SeXuality: The Right to Privacy and the Making of Roe v. Wade 335-88 (1994). In Planned Parenthood of Southeastern Pennsylvania v. Casey, 505 U.S. 833 (1992), the privacy rationale was dropped. 
not necessarily ${ }^{94}$ Black was prescient when he predicted that privacy was "a broad, abstract, and ambiguous concept which can easily be shrunken [or expanded] in meaning." 95

What to make of penumbras and emanations? ${ }^{96}$ Presumably intended to imply a tie between the core (i.e., the amendments) and the periphery (i.e., privacy), the metaphor seems unconnected with the facts of the case. Nor are the cases cited, as implying a larger privacy right, well chosen. ${ }^{97}$ How is counseling about contraceptives related to any of the amendments cited, for example, to quartering soldiers or self incrimination? ${ }^{98}$ For that matter, how is running classes counseling couples a private act? Black, dissenting, echoed Alice's complaint: "The question is ... whether you can make words mean so many different things." To which Douglas, following Humpty Dumpty, essentially replies: "The question is . . which is to be master - that's all." ${ }^{\prime 99}$ For Black, the words, that is, the Constitution, are the master; for Douglas, it is the judge. Thus, Black, though conceding that the Connecticut law is "offensive," 100 goes on to say, "I like my privacy as well as the next one, but I am nevertheless compelled to admit that government has a right to invade it unless prohibited by some specific constitutional provision." ${ }^{101}$ For Douglas, the absence of a specific provision is no problem.

And why, as in Skinner, did Douglas shine a spotlight on marriage? ${ }^{102}$ For him, the marital bedroom was a "sacred precinct," off limits to police searching for telltale signs of contraceptives. Would the police also be barred from searching it for telltale signs of guns or drugs or counterfeit bills? Would marital bedrooms be impervious to search warrants? Would the Connecticut law survive, so long as it was not enforced against married couples? Before long, the Court jettisoned the marriage rationale, extending the right to contraceptives to unmarried persons ${ }^{103}$

94 Thomas Halper, Privacy and Autonomy: From Warren and Brandeis to Roe and Cruzan, 21 J. Med. \& PHIL. 121 (1996).

95 Griswold, supra note 77, at 509.

96 Harlan derided them as "radiations." Id. at 500. Justice Thomas is said to have hung a sign in his chambers reading, "Please don't emanate in the penumbras." JefFrey Rosen, The Supreme Court: Personalities and Rivalries that Defined America 173 (2006).

97 Skinner was an equal protection case; Breard v. Alexandria, 341 U.S. 622 (1951), was a First Amendment case, Monroe v. Pape, 365 U.S. 167 (1961) and Frank v. Maryland, 359 U.S. 360 (1959) were search and seizure cases; and Lanza v. New York, 370 U.S. 139 (1962), was a due process case. The only case where privacy was mentioned was Public Utilities v. Pollak, 343 U.S. 451 (1952), and here the privacy clam was rejected.

98 At conference, when Douglas tied privacy to the freedom of assembly, Black retorted that the "right of a husband and wife to assemble in bed is a new right to me." Thereupon Paul Posner, a law clerk to Justice Brennan, drafted a letter, which Brennan sent to Douglas, suggesting tying privacy to the Third, Fourth, and Fifth Amendments. DAVID J. Garrow, Reproductive Rights and Liberties, in Passion and Reason: Justice BRENNAN's ENDURING INFLUENCE 110 (E. Joshua Rosenkranz \& Bernard Schwartz eds., 1997).

99 Lewis Carroll, Through the Looking-Glass 205 (HarperCollins Publishers 1934) (1871).

100 Griswold, supra note 77, at 507 (1965).

101 Id. at 510.

102 He had discarded his wife of twenty-eight years in 1963 to the consternation of his children: MuRPHY, supra note 72, at 289-95.

103 Eisenstadt v. Baird, 405 U.S. 438 (1972). 
and then to minors. ${ }^{104}$ No wonder the opinion generated three concurrences and two dissents.

\section{The Final Period: Sierra Club v. Morton}

Few cases so engaged Douglas as Sierra Club v. Morton ${ }^{105}$ (1972). Lauded as the "Environmental Justice"106 and the "First Supreme Court Environmentalist,"107 he was perhaps "the most prominent conservationist in public life" of his time. ${ }^{108}$ Long before the environmental movement became fashionable, Douglas was a dedicated outdoorsman, who, for instance, hiked the entire two thousand plus mile Appalachian Trail and climbed the Cascade Mountains. More than that, he was unceasingly active in efforts at preservation. For example, he was perhaps the key figure in helping to block a proposed parkway to be built along the Chesapeake \& Ohio Canal, running from Washington to Cumberland, MD. ${ }^{109} \mathrm{He}$ also wrote a series of well publicized books on the wilderness. ${ }^{110}$ These kind of activities brought him considerable renown. A portion of the Appalachian Trail is known as the Douglas Trail; his statue oversees the C \& O hiking path; and the Sierra Club established an award in his honor that is given to persons who made outstanding use of the legal/judicial process to achieve environmental goals. ${ }^{111}$

This commitment to the environment was also reflected in his opinions on the Court. In 1960, for example, Douglas took the unusual step of dissenting from a certiorari denial concerning the aerial spraying of DDT and kerosene to eradicate gypsy moths that were damaging forests. Ignoring legal considerations, he detailed the harmful pollution produced by the practice. ${ }^{12}$ Near the end of his service on the Court, he wrote a concurrence to a per curiam opinion, also very unusual, in a case upholding the Atomic Energy Commission's power to approve commercial nuclear powered electric plants. Warning of the dangers of agency abuse, he expressed his concerns regarding nuclear power. ${ }^{113}$

104 Carey v. Population Servs. Int'1, 431 U.S. 678 (1977).

105 Sierra Club v. Morton, 405 U.S. 727 (1972).

106 Adam M. Sowards, The Environmental Justice: William O. Douglas and American Conservation (2009).

107 Peter Manus, Wild Bill Douglas's Last Stand: A Retrospective on the First Supreme Court Environmentalist, 72 Temp. L. Rev. 111 (1999).

108 Stephen Cox, The American Conservationist Movement: John Muir and His LEGACY 239 (1981); SimON, supra note 67, ch. 24.

109 William O. Douglas, Potomac Sanctuary, Wash. Post, Jan. 19, 1954.

110 William O. Douglas, My Wilderness: The Pacific West (1960); William O. Douglas, My Wilderness: East to Katahdin (1961); William O. Douglas, A Wilderness Bill of Rights (1965); William O. Douglas, Farewell to Texas: A VANISHING WiLDERNESS (1967).

111 Douglas had served on the board of the Sierra Club, resigning in 1962 because it "may be engaging in litigation ... which at least in their potential might reach this Court." William O. Douglas, The Douglas Letters: Selected from the Private Papers of Justice William O. Douglas 62 (Melvin I. Urofsky \& Philip E. Urofsky eds., Adler \& Adler 1987).

112 Murphy v. Butler, 362 U.S. 929 (1960).

113 Northern Indiana Public Service Co. v. Izaak Walton League, 423 U.S. 12, 17-19 (1975). 
Sierra Club v. Morton turned on a narrow, technical question, though Douglas' argument was anything but narrow and technical. Specifically, the case was about standing. Article III authorizes federal courts to hear only "cases and controversies," which courts have interpreted to mean that "the plaintiff must have suffered an 'injury in fact,' ... that the injury has to be 'fairly traceable' to the challenged action of the defendant ... [and] it must be likely ... that the injury will be redressed by a favorable decision." "'114 Absent the injury in fact, there is no case.

Walt Disney Enterprises secured a thirty year use permit from the U.S. Forest Service to develop an eighty acre complex of motels, restaurants, and other facilities as part of a ski/summer resort in Mineral King Valley in the Sequoia National Forest. Running through the forest would also be a high voltage power line and a twenty mile highway, each tied to the development. The Sierra Club, a nonprofit organization devoted to conservation and sound maintenance of national parks, saw the proposed development as threatening to the ecology and character of Mineral King and sought to block the development in order to maintain its quasi-pristine appearance. Unsuccessful in its efforts through the political process, the Sierra Club sought a declaratory judgment that the development violated federal statutes and regulations.

The majority took the position that the Sierra Club lacked standing, and therefore could not proceed with the law suit. In order to challenge the Forest Service decision, the Sierra Club had to demonstrate a personal stake in the dispute. The Sierra Club pointed to section ten of the Administrative Procedure Act, which provides that "[a] person suffering legal wrong because of agency action, or adversely affected or aggrieved by agency action within the meaning of a relevant statute, is entitled to judicial review thereof;" as a conservation group, the Sierra Club felt sufficiently aggrieved to qualify. Justice Stewart, writing for the majority, conceded that the development "may amount to an "injury in fact," 115 but added that the Sierra Club "failed to allege that it or its members would be affected" by it. ${ }^{16}$ That the development was a public action and that the Sierra Club considered itself a representative of the public did not relieve it of its standing obligation, for if the Sierra Club could proceed, so, too, could any bona fide organization or even individual. ${ }^{117}$

In a "famous"118 impassioned dissent, Douglas begins by suggesting that standing be refashioned in cases involving environmental litigation, such as by "the conferral of standing upon environmental objects to sue for their own preservation." 119 "Inanimate objects," like ships and corporations, "are sometimes

114 Lujan v. Defenders of Wildlife, 504 U.S. 555, 560-61 (1992). For a devastating critique of the doctrine, see William A. Fletcher, The Structure of Standing, 98 Yale L. J. 221 (1988).

115 Sierra Club, supra note 104, at 734.

116 Id. at 735 .

117 Id. at 739-40. Stewart was very far from hostile to Sierra. Indeed, in footnote 8 he wrote that the decision did not bar Sierra from amending its complaint to cover individualized grievances and thereby meet the standing threshold. Sierra took the hint, amended their complaint, and won the suit.

118 Feldman, supra note 83.

119 Sierra Club, supra note 104, at 742. This argument, as he acknowledged, had recently attracted a good deal of attention: Christopher Stone, Should Trees Have Standing? Toward Legal Rights for Natural Objects, 45 S. CAL. L. Rev. 450 (1972). Art. 120 of the 
parties to litigation;" 120 indeed, "the problem is to make certain that the inanimate objects which are the very core of America's beauty, have spokesmen before they are destroyed." ${ }^{21}$ Who can perform this task? "Congress is too remote ... and its machinery is too ponderous," and federal agencies cannot be trusted because "they are notoriously under the control of powerful interests," 122 with the Forest Service "notorious for its alignment with lumber companies." 23 Only the courts remain as actors ready, willing, and able to do the job.

Few judicial opinions display so nakedly the policy preferences of their author. Douglas presents the Mineral King controversy in entirely Manichean terms, with virtuous environmentalists contesting with evil developers and co-opted regulators. Do developers generate social benefits, in the form of recreation and employment? Will bringing more people to the wilderness not only despoil it but also perhaps allow some visitors to discover its wonders and work to sustain it? For Douglas, developers are simply destroyers. One law professor who spent some time with him recalled, "He was deeply distressed at the polluted condition of the environment, blaming it all on the work of giant corporations." Then Douglas told him, "I'm ready to bend the law in favor of the environment and against the corporations." 124 The result in this case was insisting that the Sierra Club could bring an action on behalf of "valleys, alpine meadows, rivers, lakes, estuaries, beaches, ridges, groves of trees, swampland, or even air." 125

More fundamentally, Douglas' dissent poses the question as to how, in a democracy, such controversies are to be resolved. The Sierra Club and other environmental groups would apparently prefer not to have to persuade the public or its representatives, both of whom may be too doltish to comprehend the message. Instead, the Sierra Club would rather seek the assistance of an unelected, unaccountable Court. Which, in turn, raises the question: why confine judicial dominance to environmental issues? Why not permit self appointed groups to act as guardians ad litem in other areas, as well? Douglas' answer is that natural environmental inanimate objects cannot protect themselves. Of course, this rationale could easily be extended to agriculture-who protects hogs from slaughter and soy beans from herbicides? - and architecture-who protects this landmark bridge or that neighborhood store? - and art—who protects this portrait or that can of excrement? ${ }^{126}$ - or manufacturing — who protects this factory or that machine? All these other areas involve what Locke called property, mixing human

Swiss constitution requires that living creatures, including plants, be treated with dignity. See Federal Ethics Committee on Non-Human Biotechnology, The Dignity of Living Beings with Regard to Plants: Moral Considerations of Plants for THEIR Own SAKe (Apr. 2008), available at https://www.ekah.admin.ch/inhalte/ekahdateien/dokumentation/publikationen/e-Broschure-Wurde-Pflanze-2008.pdf .

120 Sierra Club, supra note 104, at 742.

121 Id. at 745.

122 Id.

${ }^{123} I d$. at 748 . The case had nothing to do with lumber companies.

124 Red Schwartz, quoted in Murphy, supra note 72, AT 455.

125 Sierra Club, supra note 104, at 743.

126 Catherine Milner, The Tate Values Excrement More Highly than Gold, Telegraph (London) (June 30, 2002), https://www.telegraph.co.uk/news/uknews/1398798/TheTate-values-excrement-more-highly-than-gold.html. 
labor with whatever the state of nature provided. ${ }^{127}$ Douglas may imagine that the "river as plaintiff speaks," 128 but its existence, not mixed with human labor, may have even less claim than Locke's property. For as it was humans who planted the beans or built the bridge or created the art, these inanimate objects would seem to have a stronger argument for human protection than a river created without human intervention. Though few take seriously the idea of defending the interests of all inanimate objects, it is difficult to see how only natural inanimate objects deserve judicial succor. And if only judges are wise enough to protect these objects, why not have them decide everything, particularly, since Douglas offers little reason to turn to Congress or federal agencies?

Relatedly, Douglas does not entertain the possibility that the economic marketplace merits respect. If people want to ski at Mineral King, for example, that activity is evidently seen as virtually the equivalent of a felony, for its value to these people or even its legitimacy is never acknowledged. The result is that this judge, who prided himself as a defender of the people, exhibits disdain for the chief ways the people exercise choice, democratically and as marketplace consumers.

\section{AUTHENTICITY}

The other day, a friend and I repaired to a local tavern, seeking respite from a long, hard day of doing very little. I ordered a glass of Goose Island IPA, which I think tastes pretty good, ${ }^{129}$ whereupon my friend berated me for drinking beer made by the Budweiser corporate behemoth. It used to be real, he informed me, but after it was bought by Budweiser, it ceased being authentic. I am not sure exactly what makes beer authentic, but I am sure that when the term is applied to the effluvia of everyday life, it plainly has become a highly prized tag.

If asked the meaning of authenticity, many might reply with that windbag Polonius' famous advice: "To thine own self be true, and it must follow, as the night the day, thou canst not then be untrue to any man." ${ }^{130}$ Yet this is not quite what authenticity means, for Polonius justifies being true to oneself with reference to dealing with others; authenticity, by contrast, justifies being true to oneself entirely by its value to oneself. Can authenticity exist, then, in mass society? That mass society generates powerful conformity pressures that war with authenticity has been a complaint of innumerable social critics. ${ }^{131}$ At the same time, though, we understand that the self does not, like babies, arrive via storks, but is to a significant extent the result of interactions with one's environment. Perhaps, then, only a hermit raised by wolves could claim perfect authenticity, in the sense that his or

John Locke, Second Treatise of Government ch. 5, § 27 (1689).

Sierra Club, supra note 104, at 743.

29 The Chicago Tribune's beer expert agrees that it is a "very solid beer"; see Josh Noel, We Rate Anheuser Busch Versions of Goose Island Beers 5 Years after Sale, CHI. TRIB., Aug. 1, 2017.

130 William ShakeSPEARE, Hamlet, act 1, sc. 3.

131 See e.g., Søren Kierkegaard, Sickness unto Death: The Christian Psychological EXPOSITION FOR UpbUILDING AND AwAKENING (Howard. V. Hong \& Edna .H. Hong eds. \& trans., Princeton University Press 1980) (1849); DAVID ReISSMAN ET AL., The Lonely Crowd: A Study of the Changing American Character (1950). 
her self is not affected or manipulated by others but is created free of external human influence, though such a person would literally be uncivilized. Moreover, as another of Shakespeare's characters observed, "All the world's a stage and all the men and women merely players;" "132 with each of us compelled by circumstances to play different roles, how to know which (if any) is authentic? The difficulties and impediments conspiring against authenticity, in short, are everywhere. The truly authentic person, triumphing over these impediments, is heroic.

There seems little doubt that Douglas regarded himself as such a person. Indeed, in memoirs and speeches, he detailed his struggles against formidable obstacles in the way of his expressing his true character and fulfilling his true destiny. As one journalist put it, "Here is a justice who refuses to conform." ${ }^{133}$ Or as Justice Clark recalled, "At conferences, Bill believed that rather than seek harmony, one should seek disharmony." ${ }^{134}$ For William Orville, Douglas was a self made man in more senses than one. In best selling writings, he described a childhood in Yakima, Washington marred by poverty and polio, which by dint of intelligence and hard work he vanquished, bringing to life the great American dream. He was not after fame or money or what William James called "the bitch goddess SUCCESS," 135 but instead was driven by an urge to make the world a better place. It was this that led him to overcome polio, build up his scrawny physique, become an outdoorsman in the Theodore Roosevelt tradition, and serve in the Army in Europe during World War I; it was this that allowed him to live uncomplaining in a tent while at college and then propelled him (via freight cars) to New York, where he worked his way through Columbia Law School, graduating second in his class; it was this that induced him to leave a white shoe law firm for academia, where he specialized in bankruptcy and corporate finance, and to leave academia for the Securities and Exchange Commission, where he soon became chairman, an informal advisor of President Roosevelt, in sum, "one of the most prominent and successful New Deal players;" 136 and it was this that at age forty saw him appointed to the Supreme Court, the youngest appointee since Joseph Story in 1811. In this elaborate narrative, the private and public selves each harmoniously illuminate the other.

Underlining this maverick persona is Douglas' writing. ${ }^{137} \mathrm{He}$ "prided himself on being the fastest writer on the Court," 138 and his opinions are brief, unencumbered by jargon or arcane references, almost conversational. They often read as if they were addressed to the educated layperson, not a sophisticated attorney or judge.

\footnotetext{
William Shakespeare, As You Like It, act 2, sc. 7.

133 Milton Viorst, Here Is a Justice Who Refuses to Conform, CHI. TriB., June 14, 1970.

134 Tom C. Clarke, J., quoted in James F. Simon, IndePendent Journey 353 (1973).

135 Letter from William James to Miss Theodora Sedgwick (Sept. 13, 1906), in 2 THE Letters of William James 260 (Henry James ed., Atlantic Monthly Press Boston 1920).

136 Feldman, supra note 83, at 169.

137 Judge Posner lists several signs of bad judicial writing — a lack of candor, concreteness, and economy of expression; overuse of jargon; preoccupation with trivia - and none of these can be found in Douglas' opinions. Richard A. Posner, Legal Writing Today, 8 SCribes J. Legal Writing 35 (2001).

138 Bob Woodward \& Scott Armstrong, The Brethren 63 (1979). His first clerk recalled that Douglas was "absolutely determined to get through [his work] and get through fast." C. David Ginsberg, quoted in Howard Ball, Loyalty, Treason and the State: An Examination of Justice William O. Douglas'Style, Substance, and Anguish, in Wasby ed., supra note 75, at 7, 35 .
} 
This was by design, for he saw his role as that of a national teacher, speaking in plain words to the public at large. ${ }^{139}$ At the same time, the opinions seem clearly the product of an impatient man. Rationales that might have produced a narrower ruling - for example, severability or ex post facto in Skinner - are not seriously considered. Central issues-like the application of the establishment clause to nonbelievers in Zorach - are sometimes avoided. The language is aggressive; basic rights to privacy, marriage, and procreation are announced as if by ukase. And it is also careless. At one point in Zorach, Douglas declares that "separation must be complete and unequivocal;" two sentences later, he tells us that this "does not say that in every and all respects there shall be separation." 140 In Griswold, he assures us that he will not act as a super legislature - and then acts as a super legislature. Where others might dress up their arguments in legal verbiage, he appears to have agreed with a colleague at the Yale Law School, his "good friend," 141 Fred Rodell, in seeing these words as "hocus-pocus." 142 For Douglas, authenticity seems to mean breaking the mold, ignoring accepted norms, going your own way. "The only soul I have to save is my own," he said, ${ }^{143}$ and though a member of a formal group, the Supreme Court, that reached decisions through voting, he "did not conceive his role as one of attempting to persuade others to his point of view." 144 His opinions, blunt and often without the usual legal apparatus, did not read like conventional opinions; his relations with his colleagues, mostly cold, brusque, and distant, did not follow standard practice. In his eyes, "He was a people's judge," unconcerned with "whether or not his views were well supported by precedent."145

Was this disdain for the views of others evidence of authenticity? To the extent that Douglas was being true to his own deepest instincts, the answer would seem to be yes. But there is a problem here, for to be fully one's own person, it is not enough to simply follow one's own instincts, for these instincts may have been implanted by other people. Douglas, it seems, never bothered developing a judicial philosophy that would guide him and protect him from being manipulated. Did he follow the text, like his colleague, Black? ${ }^{146}$ Or original public meaning, like Scalia? ${ }^{147}$ The point of such theories is to distance the judge from his own predilections, but it was precisely these predilections that Douglas wanted to follow.

We now know, too, thanks to a biographer who refused to take Douglas at his word, ${ }^{148}$ that much of Douglas' classic Horatio Alger autobiography that resonated so widely is fiction. His family was middle class, not poor; he suffered from a psychosomatic intestinal condition, not polio; he served two months in the Whitman College Student Officers Training Corps to beat the draft, not the Army; he lived at

139 SimON, supra note 67, ch.25.

140 Zorach, supra note 43, at 312.

141 Murphy, supra note 72, at 346.

142 Fred Rodell, Woe Unto You, Lawyers! 64-5 (1939).

143 Howard Ball, Loyalty, Treason and the State: An Examination of Justice William O. Douglas' Style, Substance, and Anguish, in Wasby ed., supra note 75, at 7. Douglas referred to himself as a loner: see Douglas, supra note 67, at 35.

144 Robert Jerome Glennon, Collegialism and Change Over Time, in Wasby ed., supra note 75.

145 Simon, supra note 67 , at 354.

146 Hugo Black, The Bill of Rights, 35 N. Y. U. L. Rev. 865 (1960).

147 Antonin Scalia, Originalism: The Lesser Evil, 57 U. CIn. L. Rev. 849 (1989).

148 See MurPhy, supra note 72. 
a fraternity house while at Whitman, not a tent; he rode a passenger train to New York, not freight cars; at Columbia, where he graduated fifth, his schoolteacher wife supported him; at the SEC his obsession was publicity, not cleaning up the financial industry; and for decades, he found his service on the Court a bit of a bore, the great goal of his life being the presidency, which as his friend Tommy Corcoran said, he wanted "worse than Don Quixote wanted Dulcinea."149 Apparently, his arrogance was so vast that it never occurred to him that a researcher would uncover his numerous, often pointless lies. ${ }^{150}$ His language, so different from the stereotypical stodgy legalese, branded him with authenticity. Yet authenticity for Douglas was entirely divorced from truth-telling.

\section{REALISM AND JUSTICE}

In an important study of federal judges, Epstein, Landes, and Posner make the common sense point that judges may be motivated by factors other than mechanistic detachment or ideological conviction. Among the goals they cite are satisfaction with their own job performance, collegial friendships, income, leisure time, and opportunities for promotion. ${ }^{151}$ Applying these criteria to Douglas reveals how unusual a justice he was. So slap-dash are many of his opinions that job performance, at least in the sense of judicial craftsmanship or esteem from his colleagues, does not seem a prime motivator. ${ }^{152}$ Often cantankerous and nasty, he hardly seemed to have valued highly friendship with his fellows on the Court. On the other hand, chronically short of money, income was important to him, as was leisure time, which he used to write, travel, and hike. Promotion, which Epstein, Landes, and Posner considered significant only for lower court judges, was also for years at the front of his mind, in the form of the presidency. In fundamental ways, Douglas was far from a typical Supreme Court justice.

Yet if we try to place him in the competing narratives of objectivity and realism, Douglas was clearly in the realism camp. Less than twenty years before he was born, Holmes had announced that "the life of the law has not been logic; it has been experience," $" 153$ later adding that the pretense that the law is a formal construct may

149 Joseph Lelyveld, His Final Battle: The Last Months of Franklin Roosevelt 156 (2016).

150 For example, he bragged that his grandfather, Orville, had seen combat in the battle of Vicksburg, when instead he was a deserter. Murphy, supra note 72, at 475-76.

151 EPstein, supra note 3, at ch.1.

152 According to Woodward and Armstrong, his clerks dubbed some of his opinions " "planetrip specials' because they were written after the Friday conference on an airplane, as Douglas traveled to some speaking engagement." See WOODWARD \& ARMSTRONG, supra note 138. Often, a few weeks before the end of the term, Douglas would finish his work and leave for his vacation home in Goose Prairie, sometimes neglecting even to inform his colleagues that he had left. The Court would not have completed its work, and he would phone in his votes. His colleagues resented the practice, and he did not care. Simon, supra note 67, at 432-33; Melvin I. Urofsky, Getting the Job Done: William O. Douglas and Collegiality in the Supreme Court, in Wasby ed., supra note 75, at 33, 36 (1990).

153 Oliver Wendell Holmes, JR., The Common LaW 1 (1881). 
disguise "considerations of social advantage," 154 a point he made with devastating effect in his famous dissent in Lochner. ${ }^{155}$ Around the same time, Pound derided the popular notion of mechanical jurisprudence, according to which the law is a coherent collection of premises and inferences that could be scientifically applied, leaving judges as mere technicians. ${ }^{156}$ Later legal realists, like Llewellyn ${ }^{157}$ and Felix Cohen, ${ }^{158}$ elaborated on these themes to great effect; at Yale, the very heart of the realist beast, ${ }^{159}$ Douglas encountered prominent realists, who reinforced his skeptical beliefs. By the time Douglas joined the Supreme Court in 1939, realism had achieved a dominant status in progressive opinion, and he was one of its most assertive exponents.

Douglas' legal realism perhaps was a corollary of his relentless drive for authenticity. Indeed, his entire life, as he laid it out in multiple memoirs, was that of a maverick, "a man's man," as Rodell put it, ${ }^{160}$ "about as independent a cuss as I knew," in the words of Thurgood Marshall, ${ }^{161}$ a rugged individualist, a "champion of the underdog," 162 a true man of the West with a big chip on his shoulder. What, then, is the proper role of a maverick judge? The answer, it seems, for Douglas is settled by another question: what is the proper role for anyone? ${ }^{163}$ His answer: to do justice. Now, one may reply with a well worn anecdote, involving an encounter between the great judge, Learned Hand, and Holmes. ${ }^{164}$ "Well, sir, goodbye," said a young Hand. "Do justice!" "Come here. Come here," replied Holmes. "That is not my job. My job is to play the game according to the rules." ${ }^{165}$ Or as Holmes later wrote Wu: "I hate justice, which means that I know if a man begins to talk about that, for one reason or another he is shirking thinking in legal terms." 166 For Holmes, the issue facing the judge is not what justice requires, but what the law requires. Law, though it often speaks in ethical terminology (duty, responsibility) and often has an ethical basis (thou shalt not steal/theft), is distinct from morality. ${ }^{167}$ In the

154 Oliver Wendell Holmes, Jr., The Path of the Law, in Collected Legal PaPers 184 (Harold Joseph Laski ed., Harcourt, Brace \& Co. 1920).

155 Lochner, supra note 89, at 74.

156 Roscoe Pound, Mechanical Jurisprudence, 8 Colum. L. Rev. 605 (1908).

157 Karl N. Llewellyn, A Realistic Jurisprudence - The Next Step, 30 CoLum. L. Rev. 431 (1930).

158 Felix Cohen, Transcendental Nonsense and the Functional Approach, 35 Colum. L. Rev. 809 (1935).

159 Laura Kalman, Legal Realism at Yale, 1927-1960 (1987).

160 Fred Rodell, quoted in JAMES F. SimON, INDEPENDENT JourNEY 276 (1973).

161 Fred Rodell, quoted in Melvin I. Urofsky, Getting the Job Done: William O. Douglas and Collegiality in the Supreme Court, in Wasby ed., supra note 75.

162 Ball, supra note 143, at 26.

163 Judge Posner believes that judges should be seen as "ordinary people responding rationally to ordinary incentives." Richard A. Posner, What Do Judges and Justices Maximize? (The Same Thing Everybody Else Does), 3 Sup. Cт. Econ. Rev. 1, 1 (1993).

164 Michael Herz, "Do Justice!": Variations on a Thrice-Told Tale, 82 VA. L. Rev. 111 (1996).

165 Learned Hand, A Personal Confession, reprinted in The Spirit of Liberty: Papers AND ADDRESSES 302, 306-07 (Irving Dilliard ed., Vintage Books, 3d ed. 1959) (1952).

166 Letter from Oliver Wendell Holmes, J., to John Wu (July 1, 1929), in Justice Holmes To Doctor Wu: An Intimate CorresPondence, 1921-1932, 53.

167 The notion that law is separate from morality has been called the separation thesis. Anthony D’Amato \& Arthur J. Jacobson, Justice and the Legal System 234 (1992). 
division of labor, moral concerns belong with the lawmakers and legal concerns with the judges.

For Douglas, this is a rationalization for avoiding responsibility, and he will have none of it. From his perspective, Holmes' view simply rests on an impoverished understanding of democracy, which identifies elected lawmakers as the officially designated voice of the people. "The goal of Congress," eighty-five percent of Americans agree, "should be to make the decisions that a majority of Americans would make if they had the information and time to think things over that Congress has." 168 As Godwin put it long ago, "A representative is but the mouthpiece and organ of his constituents." 169

One flaw in this view is that it connects voting to public policy in an unrealistically simplistic fashion, compelling us to infer public approval from legislative actions and ignore the agency problem. ${ }^{170}$ Large segments of the electorate neither know nor care much about politics, ${ }^{171}$ and vote for reasons only tangentially related to policy, like party or candidate personality. ${ }^{172}$ Even voters choosing to vote on a policy basis will find that a given candidate has taken a variety of positions on a number of policies; a voter may agree with some of these positions, disagree with others, and be indifferent to still others. ${ }^{173}$ In fact, it is not always easy even to define the policy in question. When President Trump calls for building a wall on the Mexican border, is the policy at issue the wall, illegal immigration or immigration generally? Or is it less a policy than a signal, ${ }^{174}$ whose true message his followers can decode? ${ }^{175}$ Even the act of asking voters their policy opinions may be problematic, as apparently such minor considerations as question

168 Steven Kull, Expecting More SaY: The American Public on Its Role in Government Decisionmaking 13-14 (1999).

169 Parke Godwin, Political Essays 40 (1856).

170 Steven A. Ross, The Economic Theory of Agency: The Principal's Problem, 63 Ам. ECON. Rev. 134 (1973). A classic study of legislator-constituency relations distinguishes between the delegate role, where the legislator expresses the constituency's "views . . . even if I personally disagree," and the trustee role, where the legislator "represents the welfare of the community as I see it." John C. WAhlKe et AL., The Legislative System: EXPLORATIONS IN LEGISLATIVE BeHAVIOR 277, 275 (1962). An analysis of 268 scholarly histories of policy change post-1945 concluded that "endogenous patterns of cooperation in governing networks," including officials, bureaucrats, lobbyists, and so forth, had far greater impact on policies than public opinion and elections. MatT Grossman, Artists Of the Possible: Governing Networks and American Policy Change Since 19457 (2014). At the same time public opinion may be permissive, allowing policy makers to act within a broad range of options, or constraining, barring them from acting.

171 Ilya Somin, Democracy and Political Ignorance: Why Smaller Government Is SMARTER, (2d ed. 2016).

172 Michael Lewis-Beck et al., The American Voter Revisited (2008).

173 The effectiveness of elite manipulation of public opinion remains in dispute. For example, Zaller emphasizes how hard it is to accomplish. JoHn R. ZALleR, THE NATURE and Origins of Mass Opinion ch. 12 (1994). For another view, see LaWRENCE R. Jacobs \& Robert Y. Shapiro, Politicians Don't Pander: Political Manipulation AND THE Loss OF DeMOcRatic Responsiveness ch. 2 (2000).

174 On signaling, see Brian L. Connelly et al., Signaling Theory: A Review and Assessment, 37 J. Mgmt. 39 (2011).

175 On decoding messages, see Glenn C. Loury, Self-Censorship in Public Discourse, 6 RATIONALITY \& SOC’y 428 (1994). 
wording ${ }^{176}$ or ordering ${ }^{177}$ may have substantial impact on opinion results. Making matters even murkier, voter preferences will vary greatly in their intensity. A voter who cares deeply about one policy may disregard candidate positions on many others that he or she cares little about. Compounding the problem, even when the public may have taken a position on an issue, lawmakers may be unaware of this position. ${ }^{178}$ If these kinds of considerations make it hard to connect voter to policy, imagine the difficulties when the voters number in the hundreds of thousands or millions, as, indeed, they regularly do.

Sometimes, as connoisseurs of false consciousness might insist, a well informed representative may know the constituencies' true interests better than they do, and so the voters may actually benefit from having their views ignored. Proposed policies, after all, might be quite complex or be closely entangled with inflammatory symbols. But just as constituents have a very imperfect understanding of their representatives, so the representatives have a very imperfect understanding of their constituents, and so even the best intentions do not insulate them from error. The representatives may misapprehend what is in their constituencies' interests or be thrown off by complexities or symbols. But, of course, we cannot always assume the best of intentions, for there is also the unavoidable matter of a conflict of interest: the representative will always have interests different from (and sometimes hostile to) his or her constituents, as well as opportunities to pursue these interests at the constituencies' expense. In this context, perhaps it is enough to say that Douglas' aggressive judging may be defended as simply one of a myriad checks and balances that reflect the Framers' obvious reservations about unadorned democracy.

Yet this argument for activist judging may misconceive democracy, too, for the connection between public opinion and public policy is far less central than the connection between electorate and representative. ${ }^{179}$ As Schumpeter wrote in his classic discussion, the great argument for democracy is that it provides a means for holding leaders accountable to the voters "by refusing to reelect them. ${ }^{180}$ It is not necessary or perhaps even desirable for the electorate to be highly knowledgeable and activist, for if it is too participatory, it may make excessive demands on government. ${ }^{181}$ Given this, what role ought unelected judges with lifetime appointment to follow? One answer is: it depends. If lawmakers act to

176 See e.g., Alec Tyson \& Carol Doherty, Polling on the Deficit: Why Question Order Matters, Pew Research Center (Dec. 20, 2013), http://pewrsr.ch/1jqqiaL.

177 See e.g., Dalia Sussman, New Poll Shows Support for Repeal of 'Don't Ask, Don't Tell', N.Y. Times: The Caucus (Feb. 11, 2010, 1:58 PM), https://thecaucus.blogs.nytimes. com/2010/02/11/new-poll-shows-support-for-repeal-of-dont-ask-dont-tell/.

178 A survey of nearly 4000 incumbent state legislators and challengers, for example, reveals that they are generally not well informed as to their constituency's preferences, even on high profile issues. See David Broockman \& Christopher Skovron, Bias in Perceptions of Public Opinion among Political Elites, 112 Am. Pol. Sci. Rev. 542 (2018).

179 Achen and Bartels in a widely discussed book argue that group attachments and social identities are key in shaping party identification, which in turn is powerful in determining voting decisions. Policy views tend to be bent to fit these factors. CHristopher H. ACHEN \& Larry M. Bartels, Democracy for Realists: Why Elections Do Not Produce RESPONSIVE GOVERNMENT (2016).

180 Joseph Schumpeter, Capitalism, Socialism, and Democracy 272 (1942).

181 Gabriel A. Almond \& Sidney Verba, The Civic Culture: Political Attitudes and Democracy in Five Nations ch. 13 (1963). 
impair democratic accountability, courts may act to open up the process, as it would be folly to expect those benefitting from the impairment to act against their own interest. Only an institution, like the courts, detached from the process, can escape the incentives supporting the violations. Arguing that the white primary should be opposed through the political process, for example, runs up against the fact that the legislators to be persuaded used the process to get elected. ${ }^{182}$ In this kind of situation, the democratic political process is incompatible with its chief rationale, accountability. The democratic process, after all, may produce anti-democratic results, and a reasonable judicial activism might be valuable in this context.

But Douglas, apparently feeling licensed to pursue justice, does not confine his activism to this kind of situation. For him, there is no hand-wringing over the counter-majoritarian difficulty ${ }^{183}$ or Thayer's rule of the clear mistake, ${ }^{184}$ both of which he apparently regards as pedantic obstacles in the way of doing justice. Where others may focus on means, he understands that it is the ends that count. Result oriented jurisprudence, then, possesses not only the candor of the realists but the moral gravitas of the serious person trying to do good.

This begs the question, however, of inquiring as to what justice is or how we are supposed to explore the question. Douglas speaks in universals that he takes to be self evident and thus need no justification. But this ignores practical controversies over the meaning of key terms that may undercut the rhetoric of universals. Does privacy, for instance, "invariably reflect very local cultural understandings, traditions, and beliefs"? ${ }^{185}$ Is marriage variable enough to include polygamy and same sex marriage? No matter. For Douglas, rights, though sometimes expressed with empathy for the individuals involved, exist only at an abstract level. Are they rooted in natural law? Unlike some other justices, who expressly follow this path, ${ }^{186}$ Douglas does not say. Do they derive from sympathy for the plight of the litigants? He does occasionally express these feelings - which are unpredictable, subjective, and therefore problematic ${ }^{187}$ - but his emphasis is always is on the larger principle entailed. The ad hoc quality of his reasoning is obvious and in the open, and lends it a certain authenticity. But its very nature poses an additional pair of questions. First, is it just for a judge to rule on the basis of standards that he or she created and did not exist at the time of the act in question? Second, what of the cost inherent in disrupting the stability of settled expectations? These are not mere quibbles, though they are ignored as such.

182 See Smith v. Allwright, 321 U.S. 649 (1944).

183 Alexander Bickel, The Least Dangerous Branch: The Supreme Court at the Bar of Politics 16 (1962).

184 James Bradley Thayer, The Origin and Scope of the American Doctrine of Constitutional Law, 7 HaRv. L. Rev. 17, 144 (1893).

185 Ronald J. Krotoszynski, JR., Privacy Revisited: A Global Perspective on the Right to Be Let Alone 184 (2016). The European Union, for example, has embraced the right to be forgotten, which the United States has rejected as abridging the freedom of speech.

186 See, e.g., Harris v. Hardeman, 55 U.S. 334, 341 (1852) (Daniel, J., delivering the opinion of the court); Butchers' Union Slaughter-House \& Live-Stock Landing Co. v. Crescent City Live-Stock Landing \& Slaughter-House Co., 111 U.S. 746, 756-57 (1884) (Field, J., concurring); Monongahela Navigation Co. v. United States, 148 U.S. 312, 327-28 (1897) (Brewer, J.).

187 Susan Bandes, Compassion and the Rule of Law, 13 InT'L. J. L. ConteXt 184 (2017). 
Also lost is accountability, for Douglas does not bother to consider how it applies to judges generally. Even assuming that Douglas somehow always spoke for justice does not eliminate the problem, for how to grant him the authority without also granting it to other judges, who might not be so blessed? How to empower Douglas, who believed in conservation, without also empowering McReynolds, who believed in white supremacy? ${ }^{188}$

Aristotle spoke of three chief modes of persuasion, logos, ethos, and pathos. ${ }^{189}$ Logos, the appeal to logic or reason, might seem the mode best suited to judicial opinions, but it is not the mode Douglas favors. Instead, he prefers ethos, an appeal to the writer's good character, and pathos, an appeal to the reader's emotions. Douglas appears to rely heavily on his own carefully cultivated reputation for straight forward, no nonsense authenticity, and at key moments, he is prone to emotional appeals, as in his reference to the police entering the sacred precinct of the marital bedroom in search of contraceptives or his disquisition on the vulnerability of nature. Logos evidently does not interest him. Indeed, the conventions of judging — close analysis of statutory text and precedents, doctrinal consistency, providing reasoned justifications, respecting traditional limits on discretion, treating his colleagues with respect - do not interest him much, either. Yet as a judge known for his openness to judicial creativity observed, "Insignificant is the power of innovation of any judge, when compared with the bulk and pressure of the rules that hedge him on every side." 190 Thus, even a friendly biographer conceded, "it was not Douglas' egocentricity ... that galled his colleagues as much as what they considered his professional irresponsibility." 191

Yet how to ensure that the maverick judge in fact does justice? Even avoiding the philosophical briar patch-what is justice? - and defining justice in terms of consensus on particular issues, what to do in cases where there may be no consensus. ${ }^{192}$ And to the extent that law requires predictability, consistency, and uniformity, what role can it offer to the maverick? Why, in any event, should we expect a maverick judge to follow a consensus? A second difficulty is that if justice is to mean more than instinctual choices, the judge must elaborate on how he or she came to his or her conclusion. This is particularly important if the judge's decision appears policy driven, for the depth of his or her expertise is often in question. Where legislators can call on a wide range of sources plus their own policy making experience, judges are far more limited in their informational resources. For Douglas, this hardly mattered. In Sierra Club, he drew on his experiences as an outdoorsman and his reading of popular works by conservationists. This was sufficient. He knew what he knew. Addressing other points of view was pointless. Though he frequently disagrees with the majority, he rarely engages them in debate. Usually, he is satisfied simply with a brief statement of his position.

\footnotetext{
188 A. Leon Higginbotham, Jr. \& William C. Smith, The Hughes Court and the Beginning of the End of the "Separate but Equal" Doctrine, 76 MinN. L. Rev. 1099, 1110 (1992).

189 See Aristotle, The Rhetoric, bk. I, ch. 1, at 1356a (W. Rhys Roberts trans. 1965). Available at http://data.perseus.org/citations/urn:cts:greekLit:tlg0086.tlg038.perseuseng1:1356a.

190 Benjamin N. Cardozo, The Nature of the Judicial Process 136-37 (1921).

191 Simon, supra note 67, at 432.

192 E.g., Louisiana ex rel. Francis v. Resweber, 329 U.S. 459 (1947); Regents of Univ. of California. v. Bakke, 438 U.S. 265 (1978).
} 
Douglas' practice of bypassing elaborate argumentation may seem to suggest a down to earth rejection of pretentious legal pomposities, the kind of ostentatious displays he ridiculed when presented by his hated rival, Frankfurter. ${ }^{193}$ Yet what they really convey is an utter lack of humility. His conclusions, as if arriving from Heaven, do not require the elaborate defenses other justices mount. It is enough that he states his views. Judging, for Douglas, entails opportunity, but not burdens, moral or intellectual. These burdens might impel others to hesitate or decide on narrow technical grounds or craft opinions qualified by conditions and contingencies or urge other bodies to take on the responsibility or become immersed in legal disputation. These legalistic responses, resting merely on long established norms and conventions, he brushes aside without explanation. For Douglas, acceding to the demands of these burdens bespeaks meekness if not cowardice, and it is hard to imagine him following this path. It might be appropriate for other justices, but certainly not for him. Yet this would seem to conflict with the conventional view of the judge's job as "settl[ing] disputes by applying pre-existing standards," 194 for when he writes of a right to marry and procreate or a right to privacy or the standing of natural things, he is quite deliberately ignoring or even renouncing the authority of pre-existing standards. ${ }^{195}$ If this subjected actors to standards unknown when they acted, it seemed a small price to pay for progress.

A practical consequence is the very limited precedential value of Douglas' opinions. The Sierra Club case, for example, provided an opportunity to develop rationales that might have served as a foundation for the emerging area of environmental law. Instead, he wrote about the standing of natural inanimate objects, an argument that he must have known would appeal to no one but himself. It may have served the expressive function of making him feel as if he were fighting the good fight, but as an instrumental means to his desired end, it was useless. Unlike the great dissenters of the past, Holmes, for example, in Lochner ${ }^{196}$ or Abrams, ${ }^{197}$ Douglas makes no real effort to persuade, and so his work has no obvious progeny. ${ }^{198}$

But there is a larger problem with Douglas' cavalier treatment of justifying his decisions, for in a free society we believe that if we can be coerced into obeying laws, we are entitled to have them publicly justified; there exists a "presumption in favor of liberty," in Feinberg's words, which means that "coercion always needs

193 After one of Frankfurter's long, professorial lectures, Douglas remarked, "When I came to conference, I thought the judgment should be affirmed [Frankfurter's position], but Felix just talked me out of it." (Simon, supra note 67, at 352).

194 Leslie Green, LaW and the Role of a Judge, in Legal, Moral, and Metaphysical Truths, 324 (K. Ferzan \& S. Morse eds., 2016).

195 This hyper-individualism also meant that Douglas was not well suited for a profession rooted in a small, tradition bound, collegial institution Even Black, for years his ally in free speech cases, refused to speak to him for an extended period. Roger K. NeWMan, Hugo Black: A Biography 532 (1997).

196 Lochner, supra note 89.

197 Abrams v. United States 250 U.S. 616, 624 (1919).

198 A polar opposite was Cardozo, who habitually suppressed his ego because he understood it as an obstacle to influence. His famous opinion in MacPherson v. Buick, 217 N.Y. 382, 111 N.E. 1050 (1916), for example, did not claim to embody major theoretical changes or policy implications, though its ramifications were immense. Also, in the interest of collegiality, he often refrained from producing dissents. 
some special justification." 199 This is especially the case when "constitutional essentials" are involved. ${ }^{200}$ Is Douglas' justification sufficient? The answer must depend upon which audience is considered. The general public will never read his opinions and, at best, be only dimly aware of them through media reports; these people hardly require much justification and presumably would be unable to make use of elaborate arguments, even if they were supplied. On the other hand, the legal and political communities have a much greater stake in the proceedings; reasoned discourse may contribute to a "will formation" that may change minds and lead to rational consensus. ${ }^{201}$ Douglas, however, in the words of one biographer, "wrote exclusively for himself." ${ }^{202}$ In the eyes of his external audience, his efforts may seem inadequate.

It finally needs to be asked whether the formalist myth Douglas and his fellow realists have worked so hard to demolish serves a social purpose. Is it, to put the matter bluntly, one of Plato's noble lies? ${ }^{203}$ Consider the notion of the independent judiciary. We all know that judges and everyone connected with the judicial enterprise are government employees. They are selected by government officials following government procedures. Their paychecks come from the Treasury Department and are drawn from funds collected by law from taxpayers. Judges rule under authority granted them by constitution and statute, and government officers enforce their decisions. Recognizing this, why should anyone go to court to resolve a dispute with the state, civil or criminal? Why expect an arm of the state to fairly address a conflict with the state? Isn't this a classic conflict of interest? In many societies - the Soviets under Stalin, Venezuela under Maduro - this would be a perfect diagnosis. If judges ignore the law, why expect anyone else to follow it? How, then, even to have a legal system? As Bickel put it, "The methods of reason and principle . . . alone justify the exercise of supreme judicial power in a democracy." 204

But in societies characterized by the rule of law, we expect and demand that judges lay aside their multiple entanglements with the state, so that we have, in Adams' famous words, "a government of law, not of men." ${ }^{205}$ This standard, of course, is not always met, but nearly everyone regards it as a legitimate goal, Douglas included. Yet his contempt for established norms and the myth of objectivity they embody is clearly at war with the presumptions underpinning judicial independence. For in case after case, he makes it clear that he is not driven by the law. In fact, he does not really try to hide it. It is his commitment to the environment or to certain social rights (like the right to marry and have children) that predetermine his decision. As time passed, his characteristic pose was to thumb his nose at, well, his colleagues, the law, anything that caught his ire. For him, the law with its superstructure of analysis was simply a means to impose policy, an

199 Joel Feinberg, Harm to Others: The Moral Limits of the Criminal Law 9 (1987).

200 John Rawls, Political Liberalism 140 (2005).

201 Jurgen Habermas, Moral Consciousness and Communicative Action 68 (1999).

202 Simon, supra note 67, at 353.

203 See Plato, Republic 414b (Allan Bloom trans., Basic Books 1968).

204 Alexander M. Bickel, The Supreme Court and the Idea of Progress 95 (1970).

205 John Adams, Novanglus (Mar. 6, 1775), in 4 The Works of John Adams, Second President of the United States: With a Life of the Author, Notes and Illustrations 106 (Charles Francis Adams ed., Little, Brown, \& Co. 1851). 
instrument of power, a political phenomenon. But the law is also a means to limit arbitrary and oppressive official conduct, and this requires that judges make a good faith effort to reach the unreachable objectivity and at the very least cultivate an appearance of objectivity.

Could Douglas have been a great judge? We will never know because the temptation to do justice prevailed over the quotidian obligations of judging. $\mathrm{He}$ was, as one writer said, "a man of action, not reflection." ${ }^{206}$ Though a United States Supreme Court justice for a record thirty-six years, he hardly seemed like a judge at all.

206 L.A. Powe, Jr., Justice Douglas after Fifty Years: The First Amendment, McCarthyism and Rights, 6 Const. Comment. 267, 271 (1989). 